\title{
KESESUAIAN KEBERADAAN RUMAH TIDAK LAYAK HUNI (RTLH) TERHADAP TATA RUANG WILAYAH DI KOTA YOGYAKARTA
}

\author{
Suitability and Strategy of un-inhabitable residence towards regional \\ spatial pattern in Yogyakarta City
}

\section{Su Ritohardoyo ${ }^{1}$, Mohammad Isnaini Sadali ${ }^{1}$}

Diterima: 18 Agustus 2017 Disetujui: 6 November 2017

\begin{abstract}
Abstrak: Kebutuhan manusia yang mendasar salah satunya adalah tempat tinggal. Kenyataannya, tidak semua tempat tinggal layak huni (RTLH). Hal ini menjadi masalah dalam mengembangkan dan menciptakan kawasan permukiman dengan kualitas lingkungan baik. Penelitian ini bertujuan menganalisis: (1) identifikasi dan pemetaan RTLH; (2) kesesuaian RTLH terhadap rencana tata ruang; dan (3) penanganan rumah tidak layak huni untuk merumuskanan strategi berdasarkan kebijakan tata ruang wilayah. Penelitian dilakukan di Kota Yogyakarta berdasarkan pendekatan spasial. Hasil penelitian menunjukkan bahwa jumlah RTLH di Kota Yogyakarta hingga tahun 2016 keseluruhan sebanyak 3.304 bangunan rumah, yang tersebar di 14 kecamatan atau 45 kelurahan. Sekitar 34,37\% RTLH di luar zona perumahan. RTLH yang berada di kawasan lindung sebanyak $13,09 \%$, terdiri dari $9,42 \%$ zona ruang terbuka hijau (RTH) dan 3,67\% pada zona suaka alam dan cagar budaya. RTLH sebanyak $21,28 \%$ berwujud hunian berada di areal pertanian. Penanganan RTLH dapat dilakukan dengan penertiban, relokasi, pembebasan lahan, maupun pemberian ganti rugi. Prioritas penanganan RTLH dapat dilakukan melalui lokasi RTLH yang berada pada kawasan lindung.Upaya yang dapat dilakukan dalam mengatasi permasalahan rumah yang layak huni dan permukiman kumuh adalah dengan memberikan dukungan kebijakan dan strategi atau program yang tepat, terpadu dan komprehensif.
\end{abstract}

Kata kunci: Kesesuaian, Rumah tidak layak huni (RTLH), Tata ruang, Strategi.

Abstract: Residence is one of the basic human rights. But, not everyone can get a place to stay that is livable. It will became a problem in developing residential areas with proper environmental quality. This research that aims to: (1) identification and mapping out where residence were un-inhabitable-UR; (2) analysis of the suitability of the UR spatial plan; and (3) analysis UR handling, to formulate strategies based on spatial policy. The study was conducted in the Yogyakarta, is based on a spatial approach. The results showed that the number of Yogyakarta's UR until 2016 is 3,304 residences, spread over 14 districts and 45 villages. Judging spatial, almost $34.37 \%$ UR are in non-residential zone. UR in non-residential zone, $13.09 \%$ are in protected areas, in the zones: $9.42 \%$ green open space, and $3.67 \%$ in the nature reserves and cultural heritage. The remaining $21.28 \%$ UR contained in non-residential area of cultivation. UR handling can be done by way of demolition, relocation, land acquisition, as well as indemnity. UR for priority handling should be done in a protected area. Efforts that can be implemented to overcome the problems UR and slums, is to provide support for policy and program strategies appropriate, integrated and comprehensive.

Keywords: Suitability, Un-inhabitable residence (UR-RTLH), Spatial Pattern, Strategy

${ }^{1}$ Program Studi Pembangunan Wilayah, Fakultas. Geografi UGM Yogyakarta. 


\section{PENDAHULUAN}

Kota layak huni dan berkelanjutan merupakan impian bagi setiap anggota masyarakat kota. Lynch, (1997) menyatakan bahwa kota yang ideal harus memenuhi beberapa syarat penting, misalnya transportasi yang memadai, sarana kesehatan, sarana air bersih, lingkungan tempat tinggal, yang memberikan kemudahan akses bagi masyarakat, baik akses pekerjaan maupun rumah dan permukiman layak tinggal. Dalam kaitannya dengan pengembangan kota Jeremy (2015) berpendapat bahwa akses tersebut lebih berorientasi kepada transportasi, yang menggunakan desain kota untuk memaksimalkan akses penggunaan transportasi umum. Hal ini akan berdampak pada urbanisasi.

Dalam kaitannya dengan perkembangan demografi dan urbanisasi regional kota, data Shell Internasional menunjukkan adanya perbedaan di setiap negara, karena itu tidak ada satupun model urbanisasi ideal yang dapat ditiru atau dicontoh oleh semua kota (Khoo, 2015). Meskipun demikian terdapat praktik terbaik yang dapat dilihat dalam pengembangan kota dan cara pengelolaannya. Dua hal yang dapat dilihat yaitu bagaimana kota harus direncanakan dengan baik melalui infrastruktur dan layanan terintegrasi yang efektif memilki sumberdaya yang lebih tinggi. Urbanisasi selain berdampak positif akan juga berdampak negatif, jika dikelola dengan tidak tepat, hal ini dapat mengakibatkan penurunan mutu, bertambahnya kerusakan lingkungan hidup, peningkatan emisi gas rumah kaca, dan masalah sosial ekonomi,

Khoo (2015) dalam mengidentifikasi jumlah penduduk di perkotaan secara absolut, hingga tahun 2007 menemukan lebih dari separuh jumlah penduduk dunia (tujuh miliar jiwa). Jumlah tersebut diprediksi dari tujuh miliar menjadi sembilan miliar pada tahun 2050. Salah satu fakta yang terjadi di perkotaan, dapat ditunjukkan akibat meningkatnya penduduk perkotaan, adalah tumbuhnya kawasan-kawasan permukiman yang tidak teratur, liar, dan tidak layak huni. Kondisi inilah yang menjadi awal perkembangan kawasan-kawasan kumuh di perkotaan, yang dihadapi hampir seluruh kota yang sedang berkembang di Indonesia.

Wilayah perkotaan adalah permukiman yang dihuni hampir $50 \%$ dari jumlah penduduk di seluruh dunia, baik di kota besar maupun di kota kecil (Tacoli, 2006). Dari jumlah penduduk perkotaan tersebut secara proporsional sebanyak $50 \%$ berada di kawasan Asia. United Nations Population Division (2007) menunjukkan bahwa pertambahan jumlah penduduk perkotaan di Indonesia pada tahun 1980, sebagian besar (57\%) tinggal di kota-kota kecil, hingga tahun 2000 meningkat menjadi $68 \%$. Sebagaimana diungkap Firman, et al. (2007) dan Fahmi, et al. (2014) bahwa laju pertumbuhan penduduk perkotaan di kota-kota kecil lebih tinggi dari pada di kotakota besar. Maknanya bahwa perkembangan penduduk perkotaan relatif tinggi dengan tingkat urbanisasi yang besar, merupakan gejala urbanisasi wilayah.

Urbanisasi berakibat pada percepatan laju pertumbuhan kota, di samping peningkatan kehidupan wilayah perkotaan, yang menuntut peningkatan permintaan dan kebutuhan penduduk kota, termasuk kebutuhan lahan untuk permukiman dan perumahan (Sadyohutomo, 2016). Tekanan penduduk terhadap lahan akan meningkat seiring dengan pertambahan jumlah penduduk, dengan bertambahnya jumlah penduduk berarti bertambah pula luas lahan yang digunakan untuk permukiman dan sarana prasarana pendukung lainnya (Sadali, 2014). Permukiman dan perumahan sebagai tempat tinggal merupakan salah satu kebutuhan dasar manusia di samping pangan, sandang dan kebutuhan rohani. Dalam Undang Undang Dasar 1945 (pasal 28), dinyatakan bahwa rumah adalah salah satu hak dasar setiap rakyat Indonesia, sehingga sebagai warga negara berhak bertempat tinggal dan mendapat lingkungan hidup yang baik dan sehat. Konsekuensinya, kebutuhan lahan permukiman terus meningkat, diikuti oleh peningkatan kebutuhan sarana prasarana umum, seiring dengan pertumbuhan penduduk.

Kecenderungan perkembangan permukiman kota di Indonesia, terutama di Kota Yogyakarta dewasa ini mengelompok pada pusat kegiatan tertentu di wilayah perkotaan. Yunus (2002) menyatakan bahwa daerah pusat kegiatan merupakan pusat kehidupan sosial, ekonomi, budaya, dan politik dalam suatu kota, sehingga terdapat bangunan-bangunan utama untuk 
kegiatan di kawasan tersebut. Kota Yogyakarta sebagai pusat kegiatan dan pelayanan memiliki daya tarik bagi beberapa penduduk yang memiliki kepentingan dan motif tertentu, sehingga menarik pendatang bertempat tinggal. Hal ini berakibat pada perkembangan permukiman beserta konsekuensinya pada perubahan kualitas lingkungan di sebagian kawasan permukiman semakin kumuh. Seperti halnya pembangunan perumahan dan permukiman di Indonesia, di Kota Yogyakarta masih dihadapkan pada tiga permasalahan pokok, yaitu keterbatasan penyediaan rumah, meningkatnya jumlah rumahtangga yang menempati rumah tidak layak huni (RTLH) dan tidak didukung oleh prasarana, sarana lingkungan dan utilitas umum yang memadai, serta permukiman kumuh yang semakin meluas (Renstra Kemenpera Tahun 2010-1014).

Keberadaan kawasan permukiman kumuh di Kota Yogyakarta masih merupakan masalah perumahan dan permukiman yang patut mendapat perhatian (Muta'ali dan Nugroho, 2016). Hasil identifikasi kawasan kumuh pada tahun 2007 menunjukkan persebarannya di 29 kelurahan Kota Yogyakarta. Dominasi kawasan permukiman kumuh berada di bantaran Sungai Code, Sungai Winongo, dan Sungai Gajah Wong, dihuni penduduk dengan kepadatan tinggi, Selain itu, sebaran lokasi permukiman kumuh juga terdapat di kawasan suburban, kawasan pinggiran rel kereta api, lingkungan sekitar pasar, dan kawasan perkampungan di tengah kota. Pada kawasan tersebut banyak terdapat bangunan RTLH, baik dari aspek rendahnya kualitas fisik bangunan maupun minimnya prasarana dan sarana penunjang permukiman. Beberapa faktor yang mempengaruhi perkembangan permukiman kumuh menurut Muhammad dan Sulistyarso (2016) adalah aspek Lingkungan (air bersih, drainase, sanitasi, sampah,aksesbilitas, Rumah sehat, dan RTH); Karakteristik ekonomi (jenis pekerjaan, tingkat pendapatan); Sosial (kepadatan penduduk, urbanisasi, budaya masyarakat, pemberdayaan masyarakat); dan Kelembagaan (kapasitas institusi, kerjasama, dan aturan berlaku). Permukiman kumuh juga memiliki karakter visual berupa ketidakserasian pada aspek orientasi, bentuk visual, tipologi, dan kelayakan huni, dengan tambahan indikasi rendahnya aspek pelayanan umum, dan fasilitas perdagangan (Purwanto, dkk., 2017).

Keberadaan kondisi RTLH tersebut, menunjukkan adanya perubahan kualitas lingkungan permukiman di perkotaan ini, yang menjadi masalah bagi masyarakat maupun pemerintah dalam mengembangkan dan menciptakan kawasan kualitas lingkungan yang baik. Di Kota Yogyakarta hingga tahun 2014 terdapat 3.304 RTLH, rumah tidak layak huni, tersebar tidak merata di seluruh kecamatan dan kelurahan. Berdasarkan pada Keputusan Walikota Nomor 393 tahun 2014 lokasi kawasan RTLH di Kota Yogyakarta, telah ditetapkan sebagai bagian dari lingkungan kritis, dan memerlukan penanganan serius agar tercipta lingkungan permukiman yang sehat, nyaman dan harmonis. Upaya yang dapat dilakukan untuk mengatasi permasalahan RTLH dan permukiman kumuh, adalah memberikan dukungan kebijakan dan strategi atau program yang tepat, terpadu, dan komprehensif. Informasi lokasi keberadaan RTLH yang jelas dan kajian kesesuaian lahan RTLH terhadap tata ruang wilayah dapat menjadi bekal awal dalam menentukan beberapa strategi penanganan RTLH di Kota Yogyakarta.

\section{Roadmap Penelitian}

Kajian mengenai rumah layak huni (RLH) dan RTLH saat ini menjadi isu yang cukup menarik karena berkaitan dengan kebutuhan dasar manusia terutama tempat tinggal. Hasil penelitian United Nation Development Programme - UNDP (2009) mengindikasikan terjadinya perluasan permukiman kumuh mencapai $1,37 \%$ setiap tahunnya, sehingga pada tahun 2009 luas permukiman kumuh diperkirakan menjadi $57.800 \mathrm{Ha}$ dari kondisi sebelumnya yakni 54.000 Ha pada akhir tahun 2004.

Badan Pusat Statistik-BPS (2007) mencatat bahwa sebanyak 21,1\% rumahtangga di Indonesia belum dapat mengakses air bersih, sebanyak 8,54\% rumah tangga masih belum mendapatkan sambungan listrik, dan sebanyak 22,85\% rumahtangga tidak memiliki akses terhadap jamban. Tingginya jumlah masyarakat yang tinggal di RTLH menjadi indikasi mengenai kondisi perekonomian masyarakat yang masih lemah, sehingga tidak mampu 
secara swadaya melakukan perbaikan ataupun peningkatan kualitas kondisi rmah tempat tinggalnya.

Pada tahun 2009 menurut Statistik Kesejahteraan Rakyat Tahun 2008 (BPS, 2008), memperkirakan 4,8 juta unit rumah dalam kondisi rusak yakni rumah dengan dua dari tiga struktur dasarnya (dinding, lantai, dan atap) memerlukan perbaikan. Selain itu, , sebanyak 13,8\% rumahtangga masih menghuni rumah dengan lantai tanah, 12,4\% dengan dinding belum permanen, dan 1,2\% tinggal di rumah yang beratap daun. Selain masalah kondisi rumah, kualitas suatu rumah juga diukur dengan tingkat aksesibilitas terhadap prasarana, sarana, dan utilitas (PSU), seperti ketersediaan air bersih, listrik dan jamban.

Pada tahun 2013 pendataan RTLH di Kota Yogyakarta telah dilakukan dan ditetapkan dalam Keputusan Walikota Nomor 393 tahun 2014, tentang penetapan lokasi kawasan RTLH di Kota Yogyakarta. Komitmen Pemerintah Kota Yogyakarta dalam menangani RTLH ditunjukkan dengan adanya basis data yang baik agar dapat dimanfaatkan dalam pengambilan keputusan atau kebijakan. Seiring dengan ditetapkannya jumlah RTLH di Kota Yogyakarta, pada tahun 2014 pemerintah Kota Yogyakarta memperkuat basis data RTLH dengan data spasial dengan maksud agar tersedia informasi kewilayahan RTLH di Kota Yogyakarta.

Hasil dari kajian dan kebijakan Pemerintah Kota Yogyakarta dapat diketahui bahwa jumlah RTLH di Kota Yogyakarta pada tahun 2013 berjumlah 3.304 unit rumah. Pemerintah Kota Yogyakarta juga melakukan pemetaan RTLH yang menghasilkan sebaran dan lokasi absolut dari masing-masing rumah. Sebaran RTLH dipetakan dan disimpan dalam data geospasial sehingga informasi keakuratan lokasi dapat dipertanggungjawabkan. Adanya pemetaan RTLH di Kota Yogyakarta, maka informasi keruangan RTLH dapat secara mudah diakses, dan membantu pemerintah dalam mengambil kebijakan dengan tepat. Kawasan yang dianggap tidak layak huni harapannya dapat ditingkatkan menjadi suatu kawasan dengan kualitas lingkungan yang baik.

Penelitian yang mengkaji kesesuaian lokasi RTLH terhadap tata ruang di Kota Yogyakarta belum pernah dilakukan. Oleh karena itu, penelitian ini dilakukan untuk menelaah dan menganalisis lebih lanjut hasil kajian yang telah dilaksanakan Pemerintah Kota Yogyakarta. Keberadaan RTLH di Kota Yogyakarta perlu dianalisis kesesuaian lahannya terhadap rencana tata ruangnya, untuk mengkaji apakah suatu objek berada pada kawasan yang sesuai (seharusnya) atau berada pada kawasan yang tidak sesuai. Oleh karenanya dilakukan penelitian yang secara umum bertujuan untuk mengungkap karakteristik dan keberadaan RTLH di Kota Yogyakarta. Secara rinci penelitian ini untuk (1) identifikasi dan memetakan keberadaan RTLH; (2) analisis kesesuaian lokasi RTLH terhadap rencana tata ruang; dan (3) analisis penanganan RTLH dengan rumusan strategi berdasarkan kebijakan tata ruang wilayah.

\section{METODE}

Pendekatan yang digunakan dalam penelitian ini adalah pendekatan rasionalistik. Pendekatan rasionalistik merupakan cara berfikir dengan mengedepankan rasio dan fakta empiris. Pendekatan rasionalistik merupakan pendekatan dengan sudut pandang berkiblat pada pemikiran peneliti sebagai landasan kebenaran, sedangkan objek atau kebendaan bersifat relatif (Sadyohutomo, 2009). Penelitian ini menggunakan metode penelitian kuantitatif dengan data sekunder sebagai data utama dan dianalisis secara deskriptif. Penelitian dilaksanakan di Kota Yogyakarta, terdiri dari 45 kelurahan pada 14 kecamatan. Kecamatan di Kota Yogyakarta adalah Kotagede, Umbulharjo, Mergangsan, Pakualaman, Gondomanan, Danurejan, Gondokusuman, Jetis, Tegalrejo, Gedongtengen, Ngampilan, Wirobrajan, Mantrijeron, dan Kraton. 
Data pokok yang dikumpulkan untuk penelitian ini berupa (1) data rumah tidak layak huni (RTLH) Kota Yogyakarta; (2) data dasar spasial atau peta Kota Yogyakarta; dan (3) dokumen RDTR dan RTRW Kota Yogyakarta dan Perda RDTR dan RTRW Kota Yogyakarta. Data dikumpulkan dari berbagai sumber seperti Kantor Statistik Kota Yogyakarta, Kantor Bappeda Kota Yogyakarta; Kantor Pemerintah Daerah Kota Yogyakarta. Di samping itu, beberapa data dikumpulkan dari 14 Kantor Kecamatan terutama data monografi yang terkait dengan judul penelitian.

Penelitian dilakukan dengan rincian tahap kegiatan sebagai berikut, (1) Inventarisasi data RTLH Kota Yogyakarta sesuai Keputusan Walikota Nomor 393 tahun 2014 tentang penetapan lokasi kawasan tidak layak huni di Kota Yogyakarta, (2) (2) Penyiapan peta dasar daerah Kota Yogyakarta, yang terdiri dari data batas-batas administrasi, jalan, sungai, serta toponiminya. (3) Input data RTLH ke dalam data spasial (peta) dengan berbasis koordinat lokasi untuk mengetahui sebaran lokasi RTLH pada tiap-tiap kelurahan. (4) Pengolahan data spasial, dengan (a) Melakukan overlay (tumpang susun) data sebaran lokasi RTLH dengan data tata ruang wilayah Kota Yogyakarta. Data tata ruang yang dipakai adalah peruntukan fungsi kawasan, hal ini berfungsi untuk melakukan evaluasi kesesuain lahan keberadaan lokasi RTLH apakah terletak di kawasan/lahan yang sesuai dengan peruntukannya atau tidak sesuai. (b) Melakukan ekspor hasil pengolahan data spasial yang berupa data tabuler dan hasil lay outing peta. (5) Analisis evaluasi kesesuaian lokasi RTLH berdasarkan arahan peruntukan fungsi kawasan pada rencana tata ruang wilayah Kota Yogyakarta. (6) Hasil dari analisis kesesuain lokasi RTLH adalah sebaran lokasi lokasi RTLH yang sesuai dan tidak sesuai. (7) Merumuskan strategi-strategi dan rekomendasi penanganan RTLH di Kota Yogyakarta, dengan tahapan

a. Kaidah-kaidah dalam merumuskan strategi penanganan RTLH:

- Aspek kebijakan: Penanganan RTLH di Kota Yogyakarta yang mengacu pada kebijakan pemerintah yang sudah ada pada tingkat provinsi atau nasional.

- Aspek biaya: kemudahan untuk akses rumah layak huni.

- Aspek infrastruktur dan sarana prasarana: pemenuhan kebutuhan infrastruktur rumah layak huni.

- Peran serta pihak terkait.

- Sosialisasi.

- Peningkatan kualitas permukiman.

b. Rekomendasi penanganan RTLH:

- Kesesuaian dengan tata ruang.

- Pemenuhan kebutuhan minimum rumah layak huni.

- Tahapan Penanganan RTLH.

- Penanganan RTLH berdasarkan prioritas.

- Perbaikan kualitas tempat tinggal dan rumah tidak layak huni.

\section{HASIL DAN PEMBAHASAN}

\section{Keberadaan dan Persebaran Rumah Tidak Layak Huni Kota Yogyakarta}

Rumah Tidak Layak Huni (RTLH) merupakan bagian dari permukiman kumuh, di dalam UU No. 1 Tahun 2011 didefinisikan sebagai permukiman yang tidak layak huni, berdasarkan pada faktor ketidakteraturan bangunan, tingkat kepadatan bangunan yang tinggi, dan kualitas bangunan serta sarana dan prasarana yang tidak memenuhi syarat. Berdasarkan pada hasil kajian Bappeda Kota Yogyakarta (2014), jumlah RTLH di Kota Yogyakarta pada tahun 2014 yaitu sebanyak 3.304 unit, yang tersebar di 45 kelurahan yang termasuk ke dalam 14 kecamatan. Jumlah tersebut sama dengan 3,55 \% dari jumlah 
bangunan rumah secara keseluruhan di Kota Yogyakarta (Tabel 1.). Kajian RTLH kembali dilakukan oleh Bappeda Kota Yogyakarta pada tahun 2015, dengan tekanan kegiatan untuk penyusunan peta geospasial RTLH. Dari hasil kajian ini menunjukkan adanya perubahan jumlah RTLH Kota Yogyakarta, yakni mengalami pengurangan sebanyak 110 unit dari jumlah sebelumnya (tahun 2014 yakni 3.304 unit), tinggal 3194 unit pada tahun 2015.

Tabel 1. Jumlah RTLH Kota Yogyakarta 2014 dan 2015

\begin{tabular}{|c|c|c|c|c|c|}
\hline \multirow{2}{*}{ KECAMATAN } & \multirow{2}{*}{ KELURAHAN } & \multicolumn{2}{|c|}{ Jumlah 2015} & \multicolumn{2}{|c|}{ Jumlah 2014} \\
\hline & & RLTH (unit) & Persen & RLTH (unit) & Persen \\
\hline \multirow[t]{4}{*}{ 1. Danurejan } & Bausasran & 33 & 10,38 & 31 & 8,88 \\
\hline & Suryatmajan & 54 & 16,98 & 61 & 17,48 \\
\hline & Tegalpanggung & 231 & 72,64 & 257 & 73,64 \\
\hline & Total & 318 & 9,96 & 349 & 10,56 \\
\hline \multirow[t]{3}{*}{ 2. Gedongtengen } & Pringgokusuman & 11 & 24,44 & 10 & 22,73 \\
\hline & Sosromenduran & 34 & 75,56 & 34 & 77,27 \\
\hline & Total & 45 & 1,41 & 44 & 1,33 \\
\hline \multirow[t]{6}{*}{ 3. Gondokusuman } & Baciro & 24 & 12,83 & 20 & 10,53 \\
\hline & Demangan & 27 & 14,44 & 27 & 14,21 \\
\hline & Klitren & 71 & 37,97 & 80 & 42,11 \\
\hline & Kotabaru & 49 & 26,20 & 49 & 25,79 \\
\hline & Terban & 16 & 8,56 & 14 & 7,37 \\
\hline & Total & 187 & 5,85 & 190 & 5,75 \\
\hline \multirow[t]{3}{*}{ 4. Gondomanan } & Ngupasan & 10 & 35,71 & 10 & 47,62 \\
\hline & Prawirodirjan & 18 & 64,29 & 11 & 52,38 \\
\hline & Total & 28 & 0,88 & 21 & 0,64 \\
\hline \multirow[t]{4}{*}{ 5. Jetis } & Bumijo & 88 & 45,13 & 95 & 45,24 \\
\hline & Cokrodiningratan & 90 & 46,15 & 96 & 45,71 \\
\hline & Gowongan & 17 & 8,72 & 19 & 9,05 \\
\hline & Total & 195 & 6,11 & 210 & 6,36 \\
\hline \multirow[t]{4}{*}{ 6. Kotagede } & Prenggan & 72 & 30,64 & 85 & 33,73 \\
\hline & Purbayan & 34 & 14,47 & 35 & 13,89 \\
\hline & Rejowinangun & 129 & 54,89 & 132 & 52,38 \\
\hline & Total & 235 & 7,36 & 252 & 7,63 \\
\hline \multirow[t]{4}{*}{ 7. Kraton } & Kadipaten & 95 & 43,58 & 96 & 44,86 \\
\hline & Panembahan & 67 & 30,73 & 68 & 31,78 \\
\hline & Patehan & 56 & 25,69 & 50 & 23,36 \\
\hline & Total & 218 & 6,83 & 214 & 6,48 \\
\hline \multirow[t]{4}{*}{ 8. Mantrijeron } & Gedongkiwo & 45 & 28,48 & 49 & 28,32 \\
\hline & Mantrijeron & 15 & 9,49 & 15 & 8,67 \\
\hline & Suryodiningratan & 98 & 62,03 & 109 & 63,01 \\
\hline & Total & 158 & 4,95 & 173 & 5,24 \\
\hline \multirow[t]{4}{*}{ 9. Mergangsan } & Brontokusuman & 361 & 52,24 & 363 & 51,13 \\
\hline & Keparakan & 40 & 5,79 & 43 & 6,06 \\
\hline & Wirogunan & 290 & 41,97 & 304 & 42,82 \\
\hline & Total & 691 & 21,63 & 710 & 21,49 \\
\hline \multirow[t]{3}{*}{ 10. Ngampilan } & Ngampilan & 76 & 66,67 & 78 & 66,67 \\
\hline & Notoprajan & 38 & 33,33 & 39 & 33,33 \\
\hline & Total & 114 & 3,57 & 117 & 3,54 \\
\hline \multirow[t]{3}{*}{ 11. Pakualaman } & Purwokinanti & 96 & 76,80 & 97 & 71,32 \\
\hline & Gunungketur & 29 & 23,20 & 39 & 28,68 \\
\hline & Total & 125 & 3,91 & 136 & 4,12 \\
\hline \multirow[t]{5}{*}{ 12. Tegalrejo } & Bener & 166 & 38,16 & 183 & 40,40 \\
\hline & Karangwaru & 61 & 14,02 & 59 & 13,02 \\
\hline & Kricak & 86 & 19,77 & 83 & 18,32 \\
\hline & Tegalrejo & 122 & 28,05 & 128 & 28,26 \\
\hline & Total & 435 & 13,62 & 453 & 13,71 \\
\hline \multirow[t]{4}{*}{ 13. Umbulharjo } & Giwangan & 45 & 17,72 & 45 & 18,29 \\
\hline & Mujamuju & 33 & 12,99 & 31 & 12,60 \\
\hline & Pandeyan & 27 & 10,63 & 25 & 10,16 \\
\hline & Semaki & 19 & 7,48 & 21 & 8,54 \\
\hline
\end{tabular}




\begin{tabular}{llrrrr}
\hline \multirow{2}{*}{ KECAMATAN } & \multirow{2}{*}{ KELURAHAN } & \multicolumn{2}{c}{ Jumlah 2015 } & \multicolumn{2}{c}{ Jumlah 2014 } \\
& & RLTH (unit) & Persen & RLTH (unit) & Persen \\
\cline { 2 - 6 } & Surosutan & 56 & 22,05 & 49 & 19,92 \\
& Tahunan & 51 & 20,08 & 52 & 21,14 \\
& Warungboto & 23 & 9,06 & 23 & 9,35 \\
14. Wirobrajan & Total & 254 & 7,95 & 246 & 7,45 \\
& Patangpuluhan & 142 & 74,35 & 144 & 76,19 \\
& Wirobrajan & 49 & 25,65 & 45 & 23,81 \\
Jumlah Keseluruhan & Total & 191 & $\mathbf{5 , 9 8}$ & 189 & $\mathbf{5 , 7 2}$ \\
& 45 Kelurahan & $\mathbf{3 1 9 4}$ & & $\mathbf{3 3 0 4}$ & $\mathbf{3 , 5 5}$ \\
& Bangunan Rumah Unit & & & $\mathbf{9 2 . 9 6 5}$ & \\
\hline
\end{tabular}

Sumber: Analisis Data Sekunder, 2017

Catatan: Persen* Perhitungan persentase RTLH setiap desa = Jumlah RTLH di desa tertentu dibagi Jumlah RTLH keseluruhan di Kecamatan terkait

* Perhitungan persentase RTLH setiap kecamatan = Jumlah RTLH di kecamatan tertentu dibagi Jumlah RTLH keseluruhan di Kabupaten Magelang

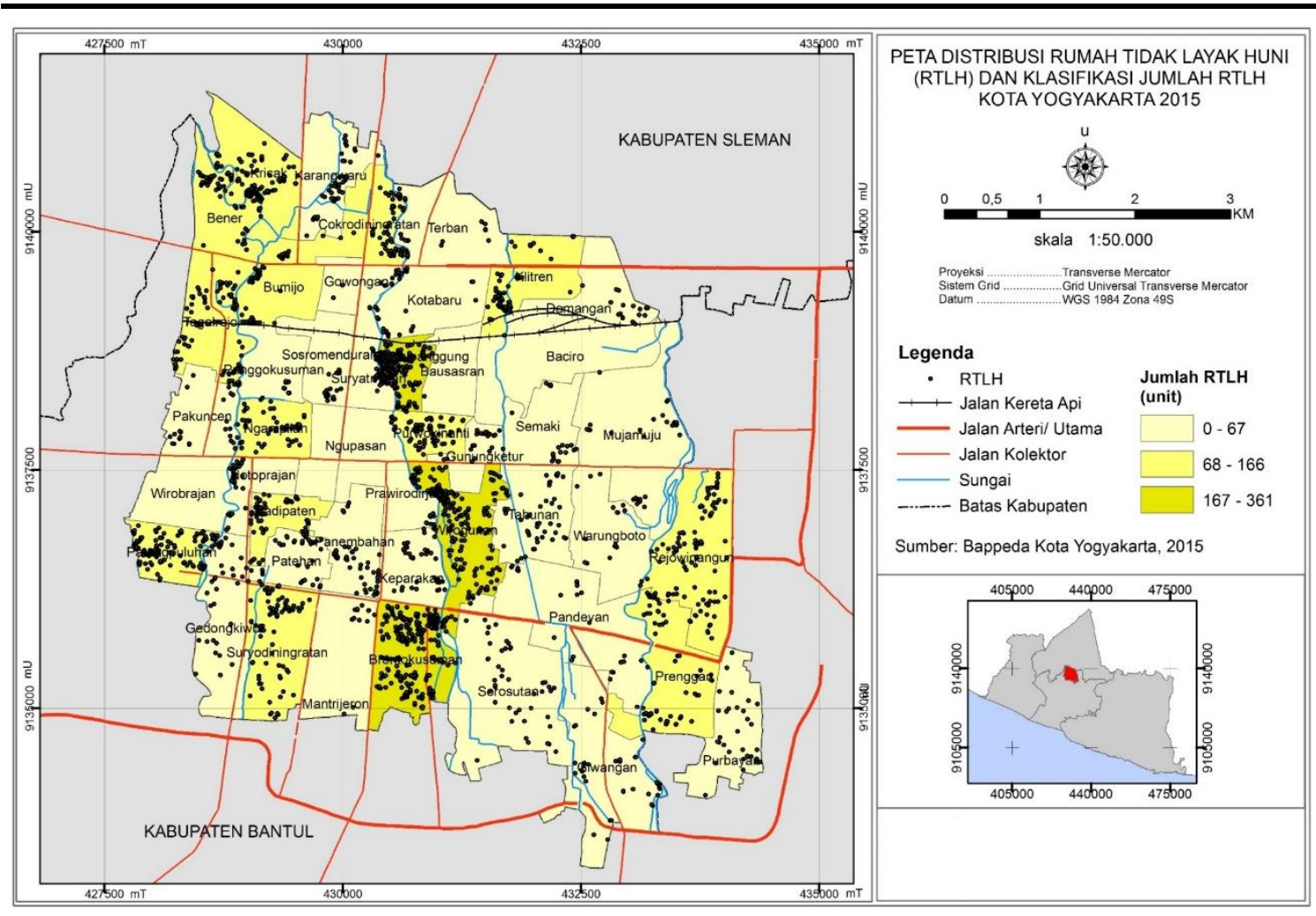

Gambar 1. Peta Distribusi Rumah Tidak Layak Huni di Kota Yogyakarta, 2015

\section{Kesesuaian Lokasi RTLH terhadap Rencana Tata Ruang}

Ditinjau dari aspek persebaran jumlah RTLH Kota Yogyakarta berdasarkan pada lokasi daerah kecamatan, paling banyak berada di Kecamatan Mergangsan (691 unit atau 21,63\% dari seluruh jumlah RTLH Kota Yogyakarta). Jumlah RTLH Kota Yogyakarta yang paling sedikit, berada di Kecamatan Gondomanan (28 unit atau 0,88\% dari seluruh jumlah RTLH Kota Yogyakarta). Apabila persebaran jumlah RTLH Kota Yogyakarta didasarkan pada lokasi daerah kelurahan, jumlah terbesar juga terdapat di Kelurahan Brontokusuman sebesar 
361 unit atau 52,24 \% dari jumlah keseluruhan RTLH di Kecamatan Mergangsan. Beberapa kelurahan lain yang memiliki jumlah RTLH cukup tinggi yaitu Kelurahan Wirogunan (290 unit atau 41,97\% dari jumlah keseluruhan RTLH di Kecamatan Mergangsan), dan di Kelurahan Tegalpanggung meskipun jumlah RTLH lebih kecil (231 unit) namun secara proporsional lebih tinggi dari pada di kedua kelurahan tersebut $(72,64 \%$ dari seluruh RTLH di Kecamatan Danurejan). Persebaran RTLH yang meningkat di Kota Yogyakarta ini juga dipicu oleh daya tarik Kota Yogyakarta daripada kota atau kabupaten sekitarnya. Kesenjangan pelayanan sarana prasarana ekonomi dan sosial yang terjadi di sekitar Kota Yogyakarta. Hal ini juga terjadi di Kabupaten Sukabumi, dimana dalam satu kabupaten saja terdapat kesenjangan sosial ekonomi karena ada kecamatan yang memiliki industri, dan ada yang tidak memiliki industri tersebut, sehingga menimbulkan permasalahan kemiskinan, pendidikan dan kesehatan antar kecamatan (Faruqi, dkk., 2015). Pengelolaan antar wilayah harusnya disesuaikan dengan karakter wilayah tersebut sehingga antar wilayah dapat saling melengkapi dan mengurangi kesenjangan. Hal ini disebabkan pengelolaan antara kota atau kabupaten kecil dengan kota besar tentunya berbeda (Setyono, dkk., 2017)

Persebaran RTLH di Kota Yogyakarta secara spasial menduduki kategori jumlah sangat banyak (lebih dari 167 unit), berada di daerah-daerah Kelurahan Brontokusuman, Wirogunan, dan Tegalpanggung; merupakan daerah perumahan yang menempati kawasan bantaran Sungai Code (Gambar 1). Beberapa kelurahan yang memiliki jumlah RTLH cukup tinggi lainnya (68-167 unit) berada di bantaran Sungai Winongo (Kelurahan Bener, Tegalrejo, Patangpuluhan) dan bantaran Sungai Gadjah Wong (Kelurahan Rejowinangun). Kondisi RTLH di Kota Yogyakarta ini banyak menempati kawasan ruang terbuka hijau (RTH) seperti sepanjang bantaran sungai. Hal ini menyebabkan luasan RTH di Kota Yogyakarta 17,78\% atau 584,45 ha, sehingga masih dibawah kondisi RTH yang ideal sekitar 30\% (Ratnasari, dkk., 2015).

Kawasan RTLH termasuk kedalam kelompok kawasan permukiman kumuh, identik dengan kawasan bantaran sungai, terutama yang terdapat di Kota Yogyakarta. Hal tersebut salah satunya disebabkan oleh faktor lingkungan permukiman dengan kepadatan tinggi (baik bangunan maupun penduduk), serta berdasarkan pula faktor lain, seperti bentuk fisik bangunan. Kawasan tidak layak huni Kota Yogyakarta juga berasosiasi dengan ketiga sungai yang melalui Kota Yogyakarta, yaitu Sungai Winongo di bagian barat, Sungai Code di bagian tengah, dan Sungai Gadjah Wong di bagian timur. RTLH paling sedikit berada di Kelurahan Ngupasan, Kecamatan Gondomanan dan Kelurahan Pringgokusuman, Kecamatan Gedong Tengen. Meskipun berada di bantaran sungai, yaitu Kelurahan Ngupasan di bantaran Sungai Code dan Kelurahan Pringgokusuman di bantaran Sungai Winongo, kedua kelurahan tersebut memiliki jumlah RTLH yang lebih sedikit dibandingkan dengan kelurahan-kelurahan lain. Menurut Santosa dan Therik (2016) perkembangan permukiman kumuh karena daya tarik dari elemen bangunan berdasar teori Doxiadis, yaitu tersedianya fasilitas umum seperti sekolah, rumah sakit, perdagangan, pusat perbelanjaan, dan transportasi. Permukiman kumuh juga memiliki ciri banyaknya bangunan liar yang tidak tertata rapi.

Pada dasarnya pemanfaatan lahan sudah seharusnya didasarkan pada rencana tata ruang wilayah. Tata ruang wilayah didasarkan pada berbagai pertimbangan, seperti aspek fisik (curah hujan, kemiringan lereng, jenis tanah, kesesuaian lahan, kemampuan lahan); sosial ekonomi (jumlah penduduk, distribusi fasilitas pelayanan, hirarki, fungsi, dan keterkaitan wilayah); penggunaan lahan existing, keberadaan infrastruktur); maupun pertimbangan lain seperti arahan rencana ke depan dari para pemangku kebijakan yang terlibat di dalamnya (Sadyohutomo, 2009; 2016).

Penentuan zona fungsi permukiman dalam tata ruang wilayah tentunya juga didasarkan atas berbagai faktor, seperti faktor fisik (berombak - datar, tanah tidak peka erosi); sosial ekonomi (keterkaitan dengan kebutuhan penduduk akan permukiman dan fasilitas pelayanan); penggunaan lahan existing, yang semula telah berkembang sebagai 
permukiman; memiliki aksesibilitas yang baik (ketersediaan infrastruktur jalan, air bersih, listrik yang memadai, kedekatan dengan pusat aktivitas). Selain itu, diperhatikan pula keberadaan zona fungsi permukiman yang tidak berada di zona fungsi lindung.

Zona fungsi lindung, baik lindung bawahan (hutan lindung) maupun fungsi lindung setempat (sempadan), dikhususkan pemanfaatannya untuk fungsi lindung saja, dan tidak seharusnya diperuntukkan pemanfaatan sebagai kawasan budidaya seperti permukiman, atau pun diperbolehkan dengan syarat dan ketentuan tertentu yang seharusnya rigid. Kawasan penyangga, sebagai peralihan antara kawasan lindung dan kawasan budidaya, memiliki pemanfaatan budidaya terbatas, sehingga diharapkan masih mampu menopang fungsi lindung. Pemanfaatan fungsi permukiman dan perumahan adalah seharusnya pada kawasan budidaya permukiman atau perumahan, sesuai dengan pembagian zona dalam rencana tata ruang wilayah (RTRW). Pembagian zona dan sub zona dalam RTRW Kota Yogyakarta adalah sebagai berikut, disajikan dalam Tabel 2.

Sebagai wilayah perkotaan, Kota Yogyakarta merupakan salah satu pusat aktivitas sosial ekonomi, memiliki penggunaan dan pemanfaatan lahan yang kompleks. Dengan kompleksitas aktivitas sosial-ekonomi, serta fungsi dan hirarki Kota Yogyakarta sebagai wilayah perkotaan dan pusat kota, Kota Yogyakarta memiliki wilayah yang sebagian besar berupa kawasan budidaya. Luas kawasan budidaya sebesar $27,74 \mathrm{~km}^{2}$, sedangkan luas kawasan lindung sebesar 3,44 $\mathrm{km}^{2}$ (Bappeda Kota Yogyakarta, 2015). Luasan kawasan lindung dan kawasan budidaya di Kota Yogyakarta masing-masing ditunjukkan pada Tabel 3.

Kawasan lindung di Kota Yogyakarta menurut RTRW sebagian besar $\left(1,9792 \mathrm{~km}^{2}\right)$ berupa Ruang Terbuka Hijau (RTH), yang didominasi oleh RTH sempadan sungai. RTH tersebar di seluruh kecamatan, dengan sempadan sungai paling luas berada di Kecamatan Tegalrejo, selanjutnya urutan kedua berada di Kecamatan Umbulharjo. Kecamatan Tegalrejo berada di bagian utara bagian daerah aliran sungai (DAS) Winongo, sedangkan Kecamatan Umbulharjo berada di bagian DAS Gadjah Wong. Untuk zona suaka alam dan cagar budaya, luasan paling besar adalah komplek perumahan PJKA, yang berada di Kecamatan Gondokusuman. Luasan sub Zona kedua yaitu cagar budaya Kotagede, namun tidak semua kecamatan memiliki zona suaka alam dan cagar budaya. Namun demikian RTH eksisting yang ada di Kota Yogyakarta saat ini hanya sekitar 18\% (Ratnasari, dkk., 2015).

Kawasan budiaya di Kota Yogyakarta sebagian besar $\left(17,4932 \mathrm{~km}^{2}\right)$ berupa zona perumahan, terutama denga kepadatan sedang-tinggi (Tabel 4.). Sebagai pusat aktivitas sosial ekonomi di DIY, tentunya Kota Yogyakarta memiliki daya tarik sebagai tempat tinggal, dengan aksesibilitas yang baik pula. Luas zona perumahan paling besar berada di Kecamatan Umbulharjo, yang memiliki zona rumah kepadatan sedang dan tinggi paling luas pula di Kota Yogyakarta. Zona rumah kepadatan sedang menyebar di seluruh wilayah Kota Yogyakarta, sedangkan rumah kepadatan tinggi terdistribusi di bagian tengah, dari utara ke selatan. Rumah kepadatan rendah hanya terdapat di Kecamatan Gondomanan, Kotagede, Pakualaman, dan Wirobrajan, dengan luasan sempit $\left(<1 \mathrm{~km}^{2}\right)$.

Zona industri berada di beberapa wilayah, yaitu berupa industri kecil, dengan luas paling besar berada di Kecamatan Wirobrajan. Zona perdagangan dan jasa berada di setiap kecamatan, paling luas berada di Kecamatan Umbulharjo. Zona perdagangan dan jasa sebagian besar berupa jenis deret, yang berasosiasi dengan jalan, menunjukkan pemilihan aksesibilitas yang tinggi. Kecamatan Umbulharjo sebagai ibukota kecamatan juga memiliki luasan paling besar untuk zona perkantoran pemerintah dan swasta. Sarana pelayanan umum tersebar di seluruh wilayah, luas terbesar di Kecamatan Gondokusuman rangking kedua di Kecamatan Umbulharjo, yang keduanya memiliki sarana pelayanan umum yakni sarana pendidikan, dan Terminal Giwangan di Kecamatan Umbulharjo. Zona peruntukan khusus memiliki luasan sempit, terdiri dari lembaga pemasyarakatan di Kecamatan Pakualaman dan zona pertahanan keamanan di Kecamatan Jetis. Zona lain, yaitu pariwisata 
di Kota Yogyakarta, terdiri dari tiga kawasan, yakni di Kecamatan Kraton, Kotagede, dan Pakualaman (Gambar 2).

Khusus perumahan sebagai zona dengan alokasi paling luas di Kota Yogyakarta, pemanfaatan lahannya sebagai tempat tinggal (rumah) berada pada zona peruntukan yang sesuai. Zona perumahan dengan kepadatan tinggi, sedang, dan rendah, sesuai dengan tingkat kepadatannya. Begitu pula dengan permukiman kumuh dan RTLH, seharusnya berada pada zona perumahan. Jika tidak, maka adanya RTLH memiliki ketidaksesuaian dengan perutukan pemanfaatan lahannya, atau dapat dikatakan sebagai permukiman liar atau illegal (squatter settlement) jika dikaitkan dengan pemanfaatan lahan yang tidak sesuai dengan RTRW.

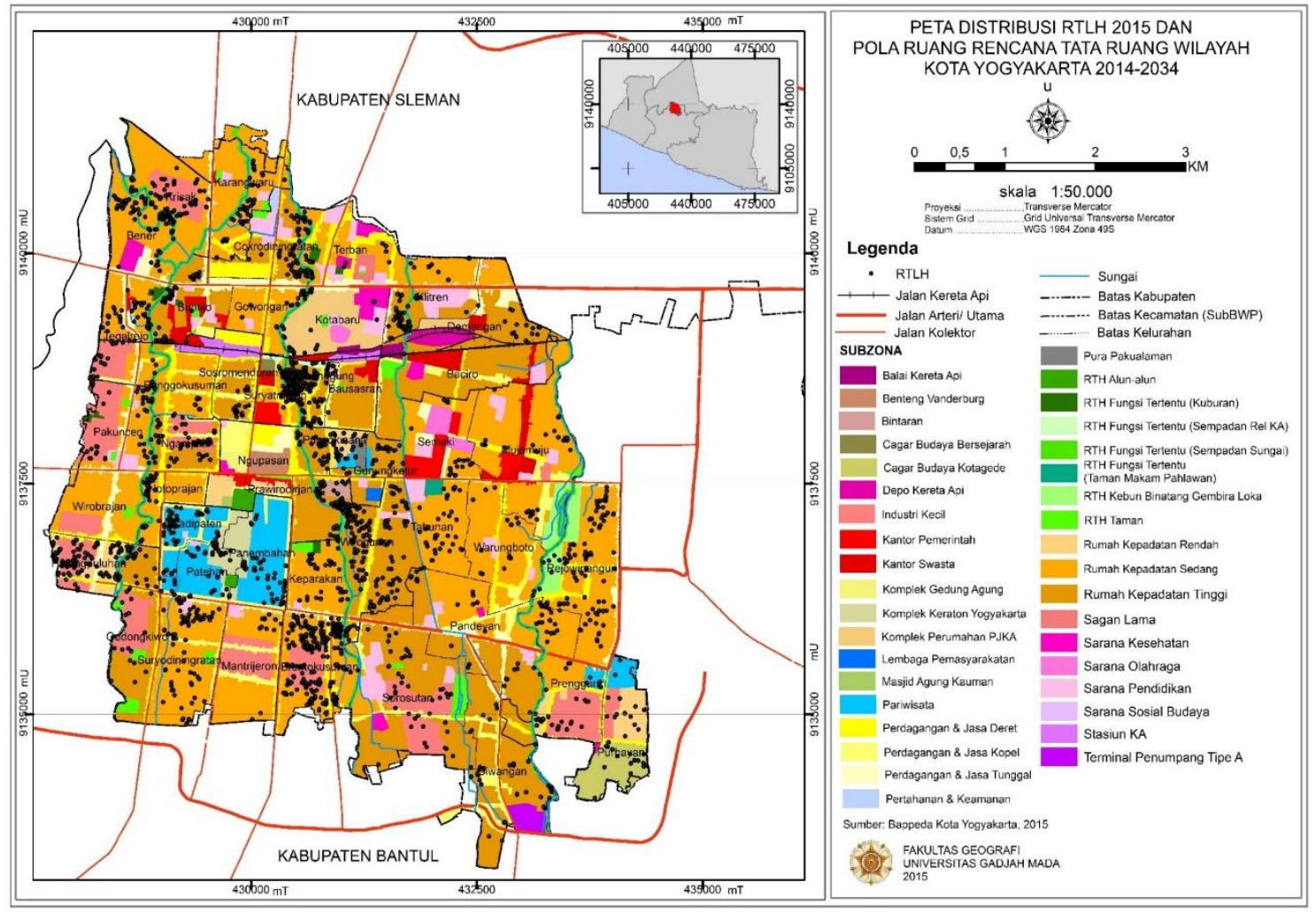

Gambar 2. Distribusi RTLH dan Pola Tata Ruang RTRW Kota Yogyakarta 2015

Berdasarkan hasil overlay antara RTRW Kota Yogyakarta dan titik lokasi RTLH, dapat dilakukan tabulasi silang antara titik lokasi RTLH (unit kelurahan dan kecamatan) dengan zona dalam RTRW. Sebanyak lebih dari 65\% RTLH berada pada zona perumahan, yang sebagian besar berada pada zona rumah kepadatan sedang. persentase dalam sub zona perumahan tersebut yaitu 32,78\% pada sub zona rumah kepadatan sedang; $29,27 \%$ pada subzona rumah kepadatan tinggi; dan 3,57\% pada subzona rumah kepadatan rendah. Pada pada subzona rumah kepadatan sedang, jumlah RTLH paling banyak berada di bantaran Sungai Code Kecamatan Mergangsan. Jumlah RTLH di Kecamatan Tegalrejo berada pada bantaran Sungai Winongo. Hal ini berarti, ada sekitar 35\% penggunaan lahan di Kota Yogyakarta tidak sesuai dengan RTRW. Nilai 35\% di Kota Yogyakarta ini lebih besar daripada di Kabupaten Cianjur yang berkisar 10,4\% (Yudarwati, dkk., 2016), dan Kota Baubau 25,3\% (Fahimuddin, dkk., 2016). Namun kedepannya jika tanpa perencanaan dan pengendalian penggunaan tata guna lahan yang baik di Kabupaten Cianjur ini juga dapat 
meningkat menjadi 20\%. Faktor-faktor penyebab ketidak sesuaian penggunaan lahan terhadap rencana pola ruang: 1) kurangnya sosialisasi kepada masyarakat, 2) tidak adanya perizinan, 3) kebutuhan tempat tinggal, 4) adanya fasilitas umum dan aksesibilitas, 5) penggunaan lahan telah ada sebelum rencana pola ruang ditetapkan, 6) berpindahnya kepemilikan lahan, dan 7) fasilitas pertanian kurang mendukung (Dani, dkk., 2017)

Ditinjau dari sebaran RTLH menurut unit kelurahan, pada subzona rumah kepadatan sedang paling banyak berada di Kelurahan Brontokusuman (Kecamatan Mergangsan). RTLH di Kelurahan Rejowinangun (Kecamatan Kotagede) berada di bantaran Sungai Gadjah Wong, juga pada subzona rumah kepadatan sedang. RTLH pada zona rumah kepadatan tinggi, sebagian besar juga berada di Kecamatan Mergangsan, dan di Kecamatan Danurejan. Kedua kecamatan tersebut berada di bantaran Sungai Code, yang dicirikan oleh jumlah RTLH Kecamatan Mergangsan paling banyak di Kota Yogyakarta. Jumlah RTLH pada zona rumah kepadatan tinggi menurut kelurahan, yang dominan di Kelurahan Wirogunan Kecamatan Mergangsan, dan di Kelurahan Tegal-panggung Kecamatan Danurejan. RTLH pada zona rumah kepadatan rendah, berada di Kecamatan Kotagede (Kelurahan Prenggan dan Purbayan); Kecamatan Pakualaman (Kelurahan Purwokinanti); dan di Kecamatan Wirobrajan (Kelurahan Patangpuluhan). Perubahan kualitas lingkungan permukiman di Kota Yogyakarta menurut Hadi dan Mulyowiyono (2003) dalam periode 1987 - 1996 sekitar $58,3 \%$. Perubahan tersebut termasuk penurunan kualitas permukiman di Kota Yogyakarta yang disebabkan oleh perkembangan permukiman secara maksimal, penambahan kepadatan bangunan, semakin kecilnya luasan tutupan vegetasi, konversi lahan pertanian menjadi permukiman dan tidak adanya kontrol masyarakat dan pemerintah untuk mengendalikan kegiatan yang berakibat penurunan kualitas lingkungan.

Ketidaksesuaian lokasi RTLH selain pada zona perumahan dapat dibedakan menjadi dua, yaitu (1) pada zona yang termasuk dalam kawasan budidaya, dan (2) pada zona yang termasuk dalam kawasan lindung. Ketidaksesuaian lokasi RTLH pada kawasan lindung tidak semestinya terjadi, karena sudah seharusnya kawasan lindung hanya difungsikan untuk fungsi lindung atau konservasi, sehingga tidak boleh terdapat fungsi budidaya di dalamnya. Kenyaataan dari hasil penelitian terdapat 13,09\% RTLH berada di kawasan lindung, yang terdiri dari $9,42 \%$ pada zona RTH, serta $3,67 \%$ pada zona suaka alam dan cagar budaya. Sebagian besar RTLH pada zona ini berada pada subzona sempadan sungai. Hal ini akibat banyaknya permukiman kumuh dan liar di bantaran sungai. Lokasi RTLH pada sempadan sungai sebagian besar berada di Kecamatan Tegalrejo, terutama berada di bantaran Sungai Winongo di Kelurahan Bener. Selain itu RTLH juga terdapat di bantaran Sungai Winongo termasuk Kelurahan Suryatmajan di Kecamatan Danurejan. Dengan demikian dapat diidentifikasi bahwa semakin banyak jumlah RTLH yang berada pada sempadan sungai, menunjukkan kedekatan lokasi rumah penduduk terhadap bibir tanggul sungai, yang seharusnya memiliki jarak (buffer) yang difungsikan sebagai sempadan.

Ketidaksesuaian lokasi RTLH juga ditunjukkan pada kawasan budidaya non perumahan sebanyak $21,28 \%$. Keberadaan RTLH pada kawasan budidaya non perumahan dapat diidentifikasi dari beberapa hal. RTLH pada kawasan budidaya non perumahan sebagian besar berada pada zona industri kecil, baik industri rumah tangga di antaranya industri pangan dan minuman, ataupun catering. RTLH yang berada pada zona industri kecil mendominasi daerah Kelurahan Brontokusuman Kecamatan Mergangsan; Kelurahan Kricak Kecamatan Tegalrejo; dan Patangpuluhan Kecamatan Wirobrajan.

RTLH pada kawasan budidaya zona non perumahan berikutnya pada zona peruntukan pariwisata. Pariwisata di Kota Yogyakarta berupa wisata budaya, diikuti eberadaan RTLH sebagian besar berada di Kelurahan Kadipaten Kecamatan Kraton. Selain itu, RTLH di zona non perumahan juga terdapat di zona perdagangan dan jasa, baik rumah deret, rumah kopel, maupun tunggal, yang sebagian besar terdapat di zona perdagangan dan jasa dalam bentuk 
bangunan rumah deret di Kelurahan Tegalpanggung Kecamatan Danurejan, dan Kelurahan Brontokusuman Kecamatan Mergangsan.

Pada zona sarana pelayanan umum, RTLH teridentifikasi pada sarana pendidikan dan sarana kesehatan, terutama pada zona sarana pelayanan umum pendidikan di Kelurahan Bumijo Kecamatan Jetis. Selain itu, terdapat dua RTLH pada zona perkantoran swasta, tetapi hal tersebut mungkin saja disebabkan lokasi yang sangat berdekatan dengan zona lainnya. Sementara itu, tidak terdapat RTLH yang teridentifikasi pada zona perkantoran pemerintah, zona peruntukan khusus,(lembaga pemasyarakatan, pertahanan dan keamanan), serta zona sarana pelayanan umum (sarana sosial budaya, sarana olahraga, terminal, stasiun, dan depo kereta api). Pada zona suaka alam dan cagar budaya, sebagian besar RTLH berada di subzona komplek keraton dan perumahan PJKA.

\section{Penanganan RTLH dengan Rumusan Strategi Berdasar Kebijakan RTRW}

RTLH merupakan salah satu permasalahan dalam perkembangan kota. Fenomena distribusi RTLH yang mengelompok memiliki potensi untuk berkembang menjadi kantongkantong kawasan kumuh. Hal tersebut disebabkan RTLH yang mengelompok dapat mengindikasikan lingkungan permukiman dan atau perumahan yang kurang sehat atau menjadi kawasan tidak layak huni. RTLH menjadi bagian dari kawasan kumuh atau kawasan tidak layak huni, akibat kualitas bangunan rumah tidak layak, seperti material bangunan yang tidak permanen atau pun tidak memiliki sarana kelayakan rumah, antara lain sanitasi. Dalam kaitannya dengan penataan perumahan dan permukiman, diperlukan upaya pengendalian RTLH dengan tujuan mencegah tumbuh berkembangnya perumahan dan permukiman kumuh, serta mencegah tumbuh berkembangnya lingkungan hunian yang tidak terencana dan tidak teratur (UU No. 1 Tahun 2011).

Mengacu pada alternatif penanganan perumahan dan permukiman kumuh dalam UU No. 1 Tahun 2011, jenis penanganan dapat berupa peremajaan, rehabilitasi, relokasi, dan rekonstruksi. Selain itu, juga terdapat upaya penanganan berupa pendekatan sosial, ekonomi, budaya dan politik yang dapat menumbuhkan nilai rasional yang maju (Triatmodjo, dkk., 2009). Untuk penanganan RTLH, secara umum dapat dilakukan upaya rehabilitasi yang dilakukan menggunakan perbaikan dan atau pembangunan kembali menjadi rumah layak huni. Tahapan rekonstruksi dan peremajaan dapat pula dilakukan pada kelompok RTLH yang barada pada kawasan permukiman kumuh atau kawasan permukiman tidak layak huni. Tahap rekonstruksi bertujuan menumbuh-kembangkan kegiatan perekonomian, sosial, dan budaya lingkungan permukiman, sedangkan peremajaan merupakan penataan secara menyeluruh, baik rumah, prasarana, sarana, dan utilitas permukiman dan perumahan. Menurut Kurniati (2014), upaya penanganan RTLH juga dapat diwujudkan dengan bentuk bangunan gedung bertingkat yang dibangun dalam suatu lingkungan yang terbagi dalam bagian-bagian yang distrukturkan secara fungsional baik dalam arah horizontal maupun vertikal dan merupakan satuan-satuan yang masing-masing dapat dimiliki dan digunakan secara terpisah, terutama untuk tempat hunian yang dilengkapi dengan bagian bersama, benda bersama, dan tanah bersama, yang kemudian dikenal dengan sebutan Rumah Susun (diatur dalam Undang-Undang No. 20 Tahun 2011 tentang Rumah Susun). Alternatif lain yang dapat diterapkan dalam penanganan RTLH maupun permukiman kumuh adalah model slum ugrading diikuti oleh konsolidasi lahan (Safarudin dkk, 2015).

Tujuan pencegahan terhadap tumbuh dan berkembangnya lingkungan hunian yang tidak terencana dan tidak teratur (UU No. 1 Tahun 2011) dapat dikaitkan dengan identifikasi RTLH pada zona RTRW yang tidak sesuai. Ketidaksesuaian lokasi RTLH yang seharusnya terdapat pada zona perumahan, tetapi berada pada zona non perumahan bahkan pada zona dengan fungsi lindung. Hal tersebut mengidentifikasikan adanya lingkungan hunian yang 
tidak terencana atau pun tidak sesuai rencana, menurut perencanaan pemanfaatan lahan dan atau ruang yang diakomodasi dalam RTRW.

Alternatif relokasi dapat dilakukan pada RTLH yang berada pada zona yang tidak sesuai, terutama RTLH yang berada di kawasan lindung (RTH, suaka alam, dan cagar budaya). Hal tersebut dimaksudkan untuk mengarahkan perkembangan perumahan dan atau permukiman pada kawasan yang seharusnya telah direncanakan, sehingga lebih teratur dan meningkatkan kualitas fungsi hunian. Selain itu, hal tersebut juga dapat dilakukan untuk mengembalikan fungsi lindung, RTH, dan sempadan sungai untuk perlindungan setempat (barrier terhadap banjir, longsor, dan ekosistem sungai). Namun demikian upaya relokasi bukan merupakan hal yang mudah karena menyangkut berbagai permasalahan, seperti lokasi tujuan pemukiman, status tanah dan pengadaan tanah, pembangunan rumah, maupun kesediaan penduduk untuk direlokasi.

Status lahan RTLH di Kota Yogyakarta bervariasi, yaitu hak milik, sultan ground, ngindung, sewa, tanah negara, dan 'wedikengser'. Secara keseluruhan, status lahan RTLH Kota Yogyakarta berupa hak milik (Bappeda Kota Yogyakarta, 2015). Begitu pula dengan status lahan RTLH yang berada pada zona lindung, sebagian besar juga berupa hak milik. RTLH dengan status lahan hak milik akan memerlukan treatment yang lebih dibandingkan dengan sultan ground dan tanah negara dan atau 'wedikengser', karena pemilikan tanah penduduk yang sah memerlukan ganti rugi yang lebih baik. Jika lahan tempat tinggal milik negara maupun kraton (sultan) maka penanganan akan lebih mudah karena terdapat otoritas pihak yang berwenang, yaitu kepemilikan atas nama negara maupun sultan atau kraton. Dengan demikian, diperlukan kajian yang lebih mendalam untuk menentukan langkah penanganan selanjutnya. Setiadi (2014) menjelaskan salah satu penanganan kawasan permukiman kumuh dapat menjadi suatu kawasan yang strategis apabila kawasan tersebut terintegrasi dengan bagian - bagian kota seperti kawasan pusat kota, kawasan pertumbuhan kota, kawasan industri, kawasan perdagangan dan kawasan perkantoran, dimana hal ini telah dikaji di Kota Bontang.

Penanganan RTLH yang berada pada kawasan budidaya zona non perumahan perlu dikaji kembali, apakah rumah tersebut memiliki fungsi ganda, baik sebagai tempat hunian maupun lokasi usaha, seperti industri kecil atau industri rumah tangga. Penanganan RTLH dengan kondisi tersebut dapat diarahkan pada pemugaran (rehabilitasi), rekonstruksi, dan peremajaan. Dalam hal ini, pada permukiman di bantaran sungai, dapat diterapkan konsep waterfront city. Permukiman penduduk sebagai lingkungan buatan dapat dipadukan dengan sungai sebagai lingkungan alam. Dengan konsep waterfront city, dapat dilakukan rehabilitasi terhadap permukiman di bantaran sungai, sehingga memiliki kualitas hunian yang baik. Selain itu, diperlukan peremajaan untuk meningkatkan kualitas prasarana, sarana, dan utilitas permukiman, serta rekonstruksi untuk mendukung terbentuknya eco-tourism yang terpadu dengan urban tourism untuk meningkatkan kondisi perekonomian masyarakat.

\section{KESIMPULAN DAN SARAN}

Pemerintah Kota Yogyakarta menetapkan kawasan tidak layak huni yang dirumuskan kedalam Keputusan Walikota Nomor 393 tahun 2014 tentang penetapan lokasi kawasan tidak layak huni di Kota Yogyakarta. Keputusan Walikota tersebut menetapkan bahwa di Kota Yogyakarta terdapat 3.304 rumah tidak layak huni (RTLH) atau 3,55 \% dari jumlah seluruh bangunan yang tersebar di seluruh 14 kecamatan dan atau 45 kelurahan. Secara spasial persebaran jumlah RTLH di Kota Yogyakarta, berdasarkan pada daerah administratif paling banyak berada di Kecamatan Mergangsan (691 unit atau 21,63\%), jumlah terbanyak terdapat di Kelurahan Brontokusuman sebesar 361 unit. Persebaran RTLH secara spatial di daerah ini dapat dijadikan dasar pertimbangan penentuan prioritas lokasi penanganan RTLH yang berpotensi menjadi permukiman kumuh. Dengan demikian dapat dinyatakan bahwa 
prioritas utama usaha penanganan RTLH diarahkan lokasinya di Kelurahan Brontokusuman Kecamatan Mergangsan.

Kawasan tidak layak huni di Kota Yogyakarta berasosiasi dengan kawasan permukiman kumuh, dan identik dengan bantaran sungai. Berdasarkan sebaran lokasinya, Kelurahan Brontokusuman, Wirogunan, dan Tegalpanggung merupakan beberapa daerah di bantaran Sungai Code. Dari ketiga Sungai Besar di Kota Yogyakarta, paling banyak rumah tidak layak huni terdapat di bantaran sungai Code. Beberapa kelurahan yang memiliki jumlah RTLH cukup tinggi lainnya (>100 unit) berada di bantaran Sungai Winongo (Kelurahan Bener, Tegalrejo, Patangpuluhan) dan bantaran Sungai Gadjah Wong (Kelurahan Rejowinangun). Pengelompokan ini berpotensi menjadikan kawasan tersebut menjadi kawasan kumuh, oleh karena itu perlu adanya penanganan dan pengurangan dengan sinergi program antar dinas/lintas SKPD.

Analisis distribusi spasial RTLH menurut kesesuaian pemanfaatan ruangnya (Rencana Tata Ruang) di Kota Yogyakarta dapat dijadikan bahan pertimbangan bagi Pemerintah Kota dalam upaya penanganan RTLH. Penanganan RTLH dapat dilakukan dengan penertiban, relokasi, pembebasan lahan, maupun pemberian ganti rugi. Prioritas penanganan RTLH dapat dilakukan melalui lokasi RTLH yang berada pada kawasan lindung (Ruang Terbuka Hijau dan Suaka Alam and Cagar Budaya).

\section{DAFTAR PUSTAKA}

Badan Perencanaan Pembangnan Daerah (Bappeda) Kota Yogyakarta, 2015. Rencana Tata Ruang Wilayah Kota Yogyakarta. Yogyakarta.

Badan Pusat Statistik (BPS). 2007. Statistik Kesejahteraan Rakyat Tahun 2007. Jakarta

Badan Pusat Statistik (BPS). 2008. Statistik Kesejahteraan Rakyat Tahun 2008. Jakarta

Badan Pusat Statistik (BPS). 2014. Statistik Kesejahteraan Rakyat Tahun 2014. Jakarta

Dani, E. T., Sitorus, S. R. P., dan Munibah, K. 2017. Analisis Penggunaan Lahan dan Arahan Pengendalian Pemanfaatan Ruang di Kabupaten Bogor. TATALOKA, 19 (1): 40 - 52. DOI: 10.14710/tataloka.19.1.4052

Fahimuddin, M. M, Barus, B., dan Mulatsih, S. 2016. Analisis Daya Dukung Lahan di Kota Baubau, Sulawesi Tenggara. TATALOKA, 18 (3): 183 - 196

Fahmi, F. Z., Hudalah, D., Rahayu, P., and Woltjer, J. 2014. Extended Urbanization in Small and Medium-size Cities. The Case of Cirebon, Indonesia. Habitat International, 42: 1-10.

Faruqi, I., Hadi S., dan Sahara. 2015. Analisis Potensi dan Kesenjangan Wilayah Kabupaten Sukabumi, Propinsi Jawa Barat. TATALOKA, 17(4): 231 - 247.

Firman, T., Kombaitan, B., and Pradono, P. 2007. The Dynamics of Indonesia's Urbanization, 1980-2006. Urban Policy and Research, 25(4): 433-454.

Hadi, B. S. dan Mulyowiyono, S. 2003. Evaluasi Perubahan Kualitas Lingkungan Permukiman Kota berdasarkan Foto Udara Multitemporal: Kasus Kecamatan Umbulharjo dengan Bantuan Sistem Informasi Geografi. $J$. Manusia dan Lingkungan, 10 (2): 63 - 73

Jeremy, B. 2015. UN State of The World Cities 2009. Ireland: European Anti Poverty Network.

Kementerian Perumahan Rakyat RI. 2014. Renstra Kemenpera Tahun 2010-2014. Dalam http://dokumen.tips/realestate/rencana-strategis-kementerian-perumahan-rakyat-renstra-kemenpera-tahun-2010-2014.html. Diunduh tanggal 1 Juni 2017,

Keputusan Walikota Nomor 393 tahun 2014 tentang Penetapan Lokasi Kawasan Tidak Layak Huni di Kota Yogyakarta. Yogyakarta: Kantor Pemerintah Daerah Kota Yogyakarta.

Khoo, T.C. 2015, New Lenses on Future Cities, Suplemen New Lens Scenarios. Singapura: Center Liveable Cities.

Kurniati, N. 2014. Pemenuhan Hak atas Perumahan dan Kawasan Permukiman yang Layak dan Penerapannya Menurut Kovenan Internasional tentang Hak-hak Ekonomi, Sosial,dan Budaya di Indonesia. Jurnal Ilmu Hukum, 1 (1): 78-98.

Lynch, K. 2009. Good City Form. Conference Paper in Computer Science and Information Engineering, 2009 WRI World Congress Hokkaido University. May 2009.

Muhammad, B. A. dan Sulistryarso, H. 2016. Arahan Penataan Lingkungan Permukiman Kumuh Kecamatan Kenjeran dengan Pendekatan Eco-Sattlements. Jurnal Teknik. 5 (2): 124-128. 
Muta'ali, L. dan Nugroho, A.R. 2016. Perkembangan Program Penanganan Permukiman Kumuh di Indonesia dari Masa ke Masa. Yogyakarta: Gadjah Mada University Press.

Nurhidayati, E., Buchori, I., dan Mussadun, M. 2016. Prediksi Perkembangan Lahan Permukiman terhadap Kerentanan Bencana Banjir dan Kebakaran di Permukiman Tepian Sungai Kapuas Kota Pontianak. TATALOKA, 18 (4): $249-260$.

Purwanto, E., Setioko, B., dan Olivia, D. 2017. Faktor - Faktor Pengaruh Kinerja Permukiman Sebagai Antisipasi Perwujudan Kampung Wisata Bahari: Studi Kasus: Kampung Nelayan Tambak Lorok, Kota Semarang. TATALOKA, 19 (1): 1 - 14. DOI: 10.14710/tataloka.19.1.1-14

Ratnasari, A., Sitorus, S. R. P., dan Tjahjono, B. 2015. Perencanaan Kota Hijau Yogyakarta Berdasarkan Penggunaan Lahan Dan Kecukupan RTH. TATALOKA, 17 (4): 196 - 208

Sadali, M. I. 2014. Trend Perkembangan Penduduk dan Implikasinya Terhadap Kebutuhan RTH (Ruang Terbuka Hijau) di D.I. Yogyakarta. Di dalam Prosiding Pertemuan Ilmiah Ikatan Geograf Indonesia (IGI). Eds. Hastuti et al. pp: 366-379. Yogyakarta: Jurusan Pendidikan Geografi UNY.

Safaruddin; S. T. dan Izziah. 2015. Penataan Perumahan Kumuh Desa Pusong Kecamatan Banda Sakti Kota Loksumawe. Jurnal Teknik Sipil. 5 (1): 61-70.

Santosa, E. B., dan Therik, L. V. 2016. Faktor Penentu Bertempat Tinggal pada Kawasan Kumuh di Kota Malang Berdasarkan Teori Doxiadis. Tata Loka, 18 (4): 261 - 273

Satyohutomo, M. 2009. Manajemen Kota dan Wilayah, Realita dan Tantangan. Jakarta: PT. Bumi Aksara

Satyohutomo, M. 2016. Tata Guna Tanah dan Penyerasian Tata Ruang. Yogyakarta: Pustaka Pelajar.

Setiadi, A. 2014. Tipologi dan Pola Penanganan Permukiman Kumuh di Kota Bontang. Tata Loka, 16 (4): 220 233.

Setyono, J. S., Yunus, H. S., dan Giyarsih, S. R. 2017. Pengelolaan Kota - Kota Kecil di Jawa Tengah: Studi Kasus pada Empat Kota Kecil di Wilayah Joglosemar. Tataloka, 19 (2): 142 - 162. DOI: 10.14710/tataloka.19.2.142-162

Sunarti dan Apriliasari, N. K. 2015. Dampak Perubahan Iklim terhadap Permukiman Pesisir di Kelurahan Demaan Kabupaten Jepara. Tata Loka, 17 (4): 248 - 256

Tacoli, C. (ed.). 2006. The Earthscan Reader in Rural-Urban Lingkages. London: Earthscan Publication.

Triatmodjo, S., Djunaedi, A., Sastrosasmito, S., dan Subroto, Y. W. 2009. Desakralisasi Ruang Cikal Bakal di Permukiman Kauman Yogyakarta: Sebuah Perubahan Makna Ruang Permukiman Tradisional di Kota. $J$. Manusia dan Lingkungan, 16 (3): 141 - 152

Undang Undang Dasar (UUD) 1945, Penjelasan Pasal 28 Sampai Pasal 28J UUD 1945. Dalam http://limc4u.com/uud-1945/penjelasan-pasal/penjelasan-pasal-28-sampai-pasal-28j-uud-1945/, $\quad$ Diunduh tanggal 1 Juni 2017.

Undang-Undang Nomor 1 Tahun 2011 tentang Perumahan Dan Kawasan Permukiman. Dalam thttp://www.hukumonline.com/pusatdata/detail/lt4d50fb4b171ba/node /39/uu-no-1tahun -2011perumahan-dan-kawasan-permu. Diunduh tanggal 1 Juni 2017

United Nations Population Division. 2007. World Urbanization Prospects. New York: Department of Economic and Social Affairs Population Division.

Yudarwati, R., Sitorus, S. R. P., dan Munibah, K. Arahan Pengendalian Perubahan Penggunaan Lahan Menggunakan Markov Celuler -Automata di Kabupaten Cianjur. Tata Loka, 18 (4): 211 - 221

Yunus, H.S. 2002. Struktur Tata Ruang Kota. Yogyakarta: Pustaka Pelajar. 